\title{
Investigation of Portland cement composites containing high amounts of different kinds of fly ashes
}

\author{
Iwona Wilińska ${ }^{1}$, Barbara Pacewska ${ }^{2}$, Wojciech Kubissa ${ }^{3}$ \\ Faculty of Civil Engineering, Mechanics and Petrochemistry, \\ Warsaw University of Technology, Plock, Poland \\ E-mail: ${ }^{3}$ wojciech.kubissa@pw.edu.pl (corresponding author)
}

\begin{abstract}
Utilization of fluidized fly ash in cement composite is problematic, e.g. because of its changeable chemical composition and increased water demand of the mixture. However, this kind of by-product shows some self-cementing properties, which may be beneficial for low-cement mixtures. The article compares the impact of various kinds of fly ashes, i.e. fluidized fly ash and conventional one, and their mixtures on hydration of fly ash-cement compositions in relation to properties of final material. The amount of fly ash in the binder was $50 \mathrm{wt} \%$. Calorimetry, thermal analysis (TG/DTG) and infrared spectroscopy were used. Compressive strength and water absorption of hardened composites were also registered. It was found that both fly ashes exhibit delay effect in fly ash-cement pastes which causes extension of initial setting time and lower heat released compared to the reference without fly ash. At later hydration days, fluidized fly ash develops higher pozzolanic activity than conventional one. Compositions with fluidized fly ash show better compressive strength compared to those containing conventional one. Mixing of different materials of high and low activity (fluidized and conventional fly ash in this case) seems to be a good way for creation of new cement replacement material.
\end{abstract}

Keywords: fly ash, HVFA concrete, cementitious supplementary materials, pozzolanic activity, hydration.

\section{Introduction}

After addition of water into cement, hydration processes start to take place resulting in release of heat which amount and intensity are different for various kinds of cement, e.g. Portland cement and calcium aluminate cement (Pacewska, Wilińska, \& Bukowska, 2009). Exothermic cement hydration are of special importance in the case of massive concrete constructions. In such case, temperature inside the element can rise considerably, while the outer layers are cooled more rapidly. Temperature gradient occurs which can cause thermal stresses. As a result, cracks may appear in the whole volume of hardened material, and concrete compressive strength and durability may be reduced (Zreiki, Bouchelaghem, \& Chaouche, 2010; Jason \& Masson, 2014; Batog, Golda, \& Giergiczny, 2016; Kuriakose, Rao, \& Dodagoudar, 2016; Jaskulski, Glinicki, Ranachowski, \& Kubissa, 2019). Taking this into account, developing new binders that release less heat during hardening than cement became necessary.

One of the ways to lower the temperature inside hydrating concrete is reduction of the amount of Portland clinker in the composite, e.g. by the use of commercially available cements CEM II - CEM V type or conventional fly ash Class F as partial cement replacement (additive type II for concrete) (Knor, Glinicki, Holnicki-Szulc, Ossowski, \& Ranachowski, 2013; Lee, Khil, \& Yun, 2014; Batog et al., 2016; Tahersima, Ley, \& Tikalsky, 2017). Concrete containing high amount (about $50 \mathrm{wt} . \%$ or higher) of fly ash in place of cement can also be considered for this purpose. Such composites are desirable not only for the reason of effective reduction of heat emission in massive constructions but also because of contribution to environmental protection. Proper use of fly ash in the concrete technology is part of pro-ecological actions of the sustainable development strategy connected with: reduction in $\mathrm{CO}_{2}$ emission, energy saving, disposal of industrial by-products, limiting the storage area of by-products of coal combustion.

Using high amount of Class F fly ash (non-hydraulic non-clinker material) as partial cement substitute in the concrete, results in elongation of initial and final setting times, slower development of compressive strength and its lower value (especially in early periods) compared to cement concrete without fly ash (Hannesson, Kuder, Shogren, \& Lehman, 2012; Huang, Lin, Chang, \& Chen, 2013; Ramezanianpour, Bayat, Bagheri, \& Moeini, 2016). In the case of massive concrete structures, limiting the exothermicity of the chemical reactions of hydration is a priority. Extended setting time may even be advantageous, ensuring proper consistency and workability for a sufficiently long time. Rate of strength increase is of secondary matter (Batog et al., 2016). However, in the case of large amount of fly ash and low content of cement, it may be difficult or even impossible to provide a suitable concrete strength class.

(C) 2019 Authors. Published by VGTU Press. This is an open-access article distributed under the terms of the Creative Commons Attribution (http://creativecommons.org/licenses/by/4.0/) License, which permits unrestricted use, distribution, and reproduction in any medium, provided the original author and source are credited. 
It happens, because cement is substituted by material which cannot harden itself but it needs $\mathrm{Ca}(\mathrm{OH})_{2}$ to reveal pozzolanic activity. Reaction between active components of fly ash and $\mathrm{Ca}(\mathrm{OH})_{2}$ goes slowly at ambient temperature (Kurdowski, 2010; Lothenbach, Scrivener, \& Hooton, 2011). Moreover, in the case of mixture of cement and low-calcium fly ash, without additional components, $\mathrm{Ca}(\mathrm{OH})_{2}$ is provided only by hydration of cement. As a consequence, in the case of high cement replacement, compressive strength of hardened material can be low even after a long time (Sun, Shen, Tan, \& Tanner, 2018). To counteract these inconveniences, reduction of water/cement ratio and using superplasticizers or different activation processes (chemical, mechanical) can be used (Jackiewicz-Rek, 2010; Garcia-Lodeiro, Donatello, Fernández-Jiménez, \& Palomo, 2016; Wilińska \& Pacewska, 2018), depending on cement replacement ratio and properties of cement substitute. Using supplementary cementitious material exhibiting self-cementing properties (instead of conventional fly ash) in concrete should also be considered. Such features and pozzolanic activity are shown by fly ash from fluidized combustion of coal.

Fluidized combustion of coal is more of a ecologically friendly technology compared to conventional pulverised combustion. However, fly ash which is formed in such combustion installation (fluidized fly ash) has significantly different properties compared to conventional Class F fly ash. Fluidized fly ash is composed of irregular porous grains (contrary to spherical vitreous grains of conventional fly ash). It contains higher amount of calcium compounds including $\mathrm{CaSO}_{4}$ (Pacewska, Blonkowski, \& Wilińska, 2008; Li, Chen, Huang, Ma, \& Wu, 2012; Sheng, Li, \& Zhai, 2012; Xia, Yan, \& Hu, 2013; Škvára et al., 2016; Zhang, Choi, Sagawa, \& Hama, 2017; Wilińska \& Pacewska, 2019). Properties of this kind of fly ash do not meet PN-EN 450-1 (Polski Komitet Normalizacyjny, 2012) standard requirements for fly ash to be used in concrete. Its utilization in cementitious composites poses some difficulties, such as deterioration of the workability of the mixture, possible highly exothermic hydration (depending on the amount of free $\mathrm{CaO}$ ), highly alkaline $\mathrm{pH}$ of the water extract, possibility of excessive expansion of formed products, especially dangerous when it occurs after the material has hardened (Li et al., 2012; Škvára et al., 2016). Exothermic fly ash hydration can cause that effective reduction of heat emission in massive concrete blocks may be impossible. Moreover, changeable chemical composition of fluidized ashes is also problematic.

In spite of the above mentioned difficulties, fluidized fly ash has potential as a material exhibiting self-cementing properties (Pacewska et al., 2008; Li et al., 2012; Sheng et al., 2012; Xia et al., 2013; Škvára et al., 2016; Zhang et al., 2017). Thus, it can be considered as cement replacement in low-cement concretes to improve some of their properties which are worsen in the case of using conventional Class F fly ash. Heat release and excessive expansion of such compositions should be under special consideration.

There are attempts to use fluidized fly ash in cement composite in typical amount - not exceeding $30 \%$ of binder mass (Pacewska, Blonkowski, \& Wilińska, 2006; Pacewska, Wilińska, \& Nowacka, 2011; Shen, Qian, \& Zhang, 2013; Gazdič, Fridrichová, Kulísek, \& Vehovská, 2017). Some studies show that fluidized fly ash can also be considered as component used in higher amount in cement-fly ash binder (sometimes also with introduction of additional chemicals) (Xia et al., 2013; Chen, Gao, Yan, \& Liu, 2017; Horszczaruk \& Brzozowski, 2018). Recently, this kind of fly ash is also proposed as component of non-clinker binder made of mixture of different industrial by-products (Dung, Chang, \& Chen, 2014; Zhang et al., 2017; Kledyński, Machowska, Pacewska, \& Wilińska, 2017; Hlaváček, Šulc, Šmilauer, Rößler, \& Snop, 2018; Machowska, Kledyński, Wilińska, \& Pacewska, 2019).

In the paper, utilization of fluidized fly ash (alone or in mixture with conventional one) in high volume fly ash concrete (50 wt.\% of cement substitution) and without additional activating components was proposed. In this way, self-cementing and pozzolanic properties of fluidized fly ash are disclosed and their influence on properties of cement material can be observed. Features of binding materials strictly depend on chemical and physical processes taking place in the hydrating system. The aim of this work is to compare the impact of various kinds of fly ashes and their mixture on hydration of fly ash-cement compositions in relation to properties of final material.

\section{Materials and methods}

\section{Materials and sample preparation}

Fly ash from fluidized combustion of hard coal (PF), fly ash from conventional combustion of the same kind of coal (PK) as well as commercially available Portland cements CEM I 32.5R and CEM I 42.5R were used to prepare the composites. Average chemical compositions (wt. \%) of fly ashes were as follows:

- for PF: $55 \% \mathrm{SiO}_{2}, 16 \% \mathrm{Al}_{2} \mathrm{O}_{3}, 5 \% \mathrm{Fe}_{2} \mathrm{O}_{3}, 10 \% \mathrm{CaO}, 5 \% \mathrm{SO}_{3}, 2.5 \% \mathrm{Na}_{2} \mathrm{O}+\mathrm{K}_{2} \mathrm{O}, 2 \% \mathrm{MgO}$,

- for PK: $50 \% \mathrm{SiO}_{2}, 20 \% \mathrm{Al}_{2} \mathrm{O}_{3}, 7 \% \mathrm{Fe}_{2} \mathrm{O}_{3}, 5 \% \mathrm{CaO}, 1 \% \mathrm{SO}_{3}, 3.5 \% \mathrm{Na}_{2} \mathrm{O}+\mathrm{K}_{2} \mathrm{O}, 3 \% \mathrm{MgO}$.

The main crystalline components of fly ashes are: quartz and mullite in the case of PK, quartz, anhydrite and calcite in the case of PF. PK almost does not contain moisture, while PF shows small amount (about $1.5 \%$ ) of adsorbed water. $\mathrm{pH}$ value of water extracts are alkaline (above 11) for both fly ashes. Other properties of PF and PK can be found in Wilińska and Pacewska (2019).

Cement-fly ash pastes were carried out using 50 wt.\% of PF (or PK) and 50 wt.\% of cement. In the case of binder containing mix of fly ashes, 25 wt.\% of PF, 25 wt.\% of PK and 50 wt.\% of cement were used. Dry components were firstly mixed, then distilled water was added in an amount ensuring water to binder ratio equal 0.6 and 
then all constituents were mixed. Reference sample was prepared without fly ash (cement + water, w/c $=0.6)$. Cement-fly ash pastes used for measurements of heat release after addition of water were hydrated in calorimeter. Specimens for thermogravimetry (TG/DTG) and infrared spectroscopy (IR) investigations were hydrated in small sealed bags at room temperature. At the appointed time, the specimens were removed from the bags and hydration was stopped by the use of acetone.

Cement-fly ash concrete series were made according to procedure described in Kubissa, Wilińska, and Pałuba (2013). Composition of binder and amount of water used to prepare concrete were the same as in the case of cement-fly ash pastes $(50 \%$ of cement replacement, water/binder $=0.6)$.

Cement-fly ash mortars containing $25 \mathrm{wt} \%$ of PK, PF or their mixture were prepared to estimate pozzolanic activity of fly ashes and their mixture. Standard sand, Portland cements CEM I 32.5R and 42.5R as well as tap water (water/binder $=0.5$ ) were used. The specimens were prepared according to PN-EN 1015-2 (Polski Komitet Normalizacyjny, 2002) standard. Pozzolanic activity index was calculated according to PN-EN 450-1 (Polski Komitet Normalizacyjny, 2012) standard. The mortars were water cured till $28^{\text {th }}$ and $90^{\text {th }}$ day of hydration.

Additionally, cement-fly ash mortars containing $50 \%$ of PF, PK or PF + PK as cement replacement were made. Portland cement CEM I 32.5R, tap water and river sand were used. Water to binder ratio was 0.6 for specimens containing PK and the mix of the two kinds of fly ashes. In the case of sample containing 50\% of PF, higher amount of water was used $($ water/binder $=0.77)$ to improve workability of the mixture without additional introduction of chemical admixtures.

\section{Methods}

Calorimetric measurements were carried out by means of differential BMR calorimeter constructed at the Institute of Physical Chemistry of Polish Academy of Sciences. External temperature was $25^{\circ} \mathrm{C}$. Specimens $(10 \mathrm{~g}$ of binder and $6 \mathrm{~g}$ of water) were hydrated in the calorimeter till $48 \mathrm{~h}$. The measurements were started immediately after addition of water into binder. The results were calculated using computer software (Poznański, 2012).

Thermal analysis (TG/DTG) was conducted using SDT 2960 Thermoanalyser (TAInstruments). The conditions of the measurements were as follows: heating rate $10^{\circ} \mathrm{C} / \mathrm{min}$, mass of sample: $9-13 \mathrm{mg}$, nitrogen atmosphere.

To collect IR spectra, FTIR spectrophotometer Genesis II, produced by Mattson (4000-400 $\mathrm{cm}^{-1}$, sample preparation - pelletizing with $\mathrm{KBr}$ ) was used.

Consistency of fresh mixtures was estimated according to the PN-EN 196-1:2016-07 (Polski Komitet Normalizacyjny, 2016) standard. The test of compressive strength and water absorption coefficient were carried out according to PN-EN 196-1:2016-07 and PN-EN 1015-18 (Polski Komitet Normalizacyjny, 2003) standards respectively.

\section{Results and discussion}

\section{Pozzolanic activity index}

Figure 1 shows pozzolanic activity indexes calculated basing on compressive strength of cement mortars containing $25 \%$ of fly ash. The measurements were carried out for Portland cement CEM I 32.5R because this kind of cement was used in the case of 50\% fly ash-cement composites, and for CEM I 42.5R as such cement is required in the PN-EN 450-1 standard.
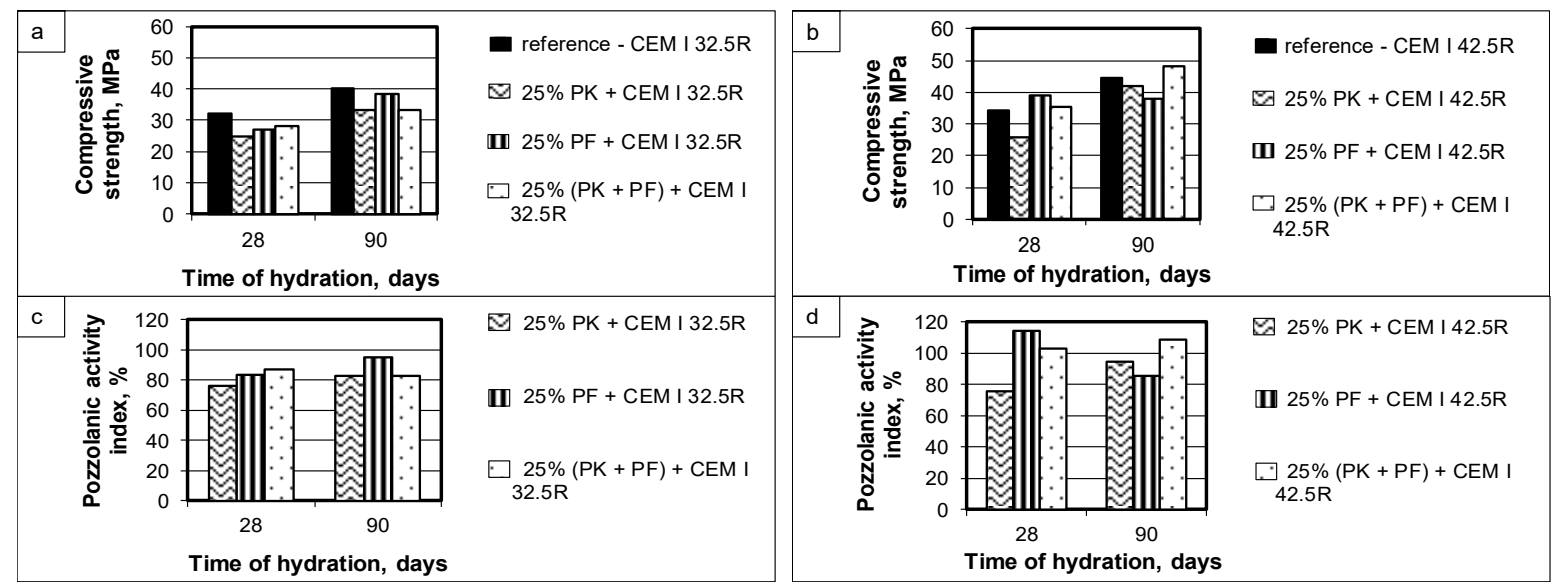

Figure 1. Compressive strength of cement-fly ash mortar (a, b) and pozzolanic activity index (c, d) 
It is visible, especially for mortar containing PF, that in presence of higher class cement, fly ash can develop its activity quicker. This is the result of more intense hydration of CEM I 42.5R cement compared to CEM I 32.5R, and, as a consequence, higher hydration heat and formation of $\mathrm{Ca}(\mathrm{OH})_{2}$ in greater amount (Pacewska \& Wilińska, 2013). Such conditions are favourable to develop pozzolanic activity of fly ash. As a result CEM I 42.5R cement mortars containing PF show 28-day compressive strength exceeding the value registered for reference. Slightly lower compressive strength was registered for mix containing PF + PK. Results obtained for CEM I 42.5R mortars after 90 days of hardening show that PK significantly develops its activity reaching compressive strength close to the reference (90-day pozzolanic activity index amounts to 95\%). 25\% PF-CEM I 42.5R cement mortar does not raise its compressive strength after $28^{\text {th }}$ day of curing. It may indicate that PF develops its activity mainly during the first 28 days and does not contribute to the increase of strength in the later period. However formation of delayed ettringite and its negative influence on compressive strength cannot be excluded. The highest 90-day compressive strength was registered for sample containing mixture PK + PF. It indicates synergic effect of both kinds of fly ash.

In the case of mortars with CEM I 32.5R Portland cement, fly ashes develop their activity more moderately compared to specimens with higher class cement. Compressive strength of cement-fly ash mortars do not exceed the result for reference. Nevertheless, pozzolanic activity index achieved satisfactory values - about $80 \%$ and even $95 \%$ (after 90 days) for sample containing $25 \%$ of PF.

\section{Research of cement-fly ash paste}

Figure 2 presents the amount of heat released after different stages of hydration, starting from $1^{\text {st }} \mathrm{h}$ and ending at $48^{\text {th }} \mathrm{h}$. As cement hydration process is exothermic, heat release is observed just after addition of water into cement-fly ash binder. This is an effect of grains wetting, dissolving of some components of the binders and finally precipitation of solid products. The amount of heat released is lower for pastes containing ashes compared to the reference sample throughout the test period. It indicates that clinker minerals and their reaction with water are mainly responsible for exothermic process. However, in the first hours after adding water, the amount of heat evolved by cement-fly ash pastes is higher than resulting from percentage replacement of cement. The heat registered for blended cement pastes amounts to above $60 \%$ of the reference value and even above $80 \%$ in the case of paste containing $50 \%$ of PF (till $4^{\text {th }} \mathrm{h}$ ). It indicates nucleation and acceleration action of fly ash grains toward cement. In the case of pastes containing $\mathrm{PF}$, porous structure of its grains, hydration of free $\mathrm{CaO}$ as well as initiation of hydration of active components of PF also contribute to this heat release.
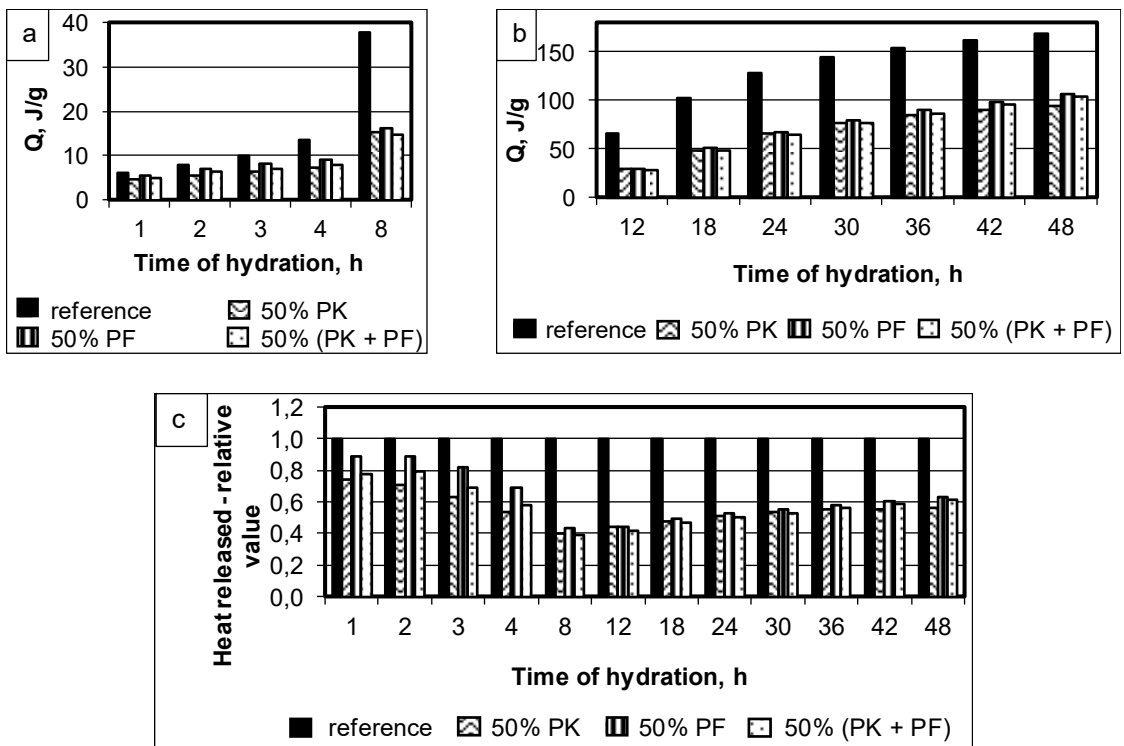

Figure 2. Total heat released after different time of hydration $(a, b)$ and relative value of the heat evolved (c)

Sample with $50 \%$ of PF exhibits the highest heat released (compared to paste with $50 \%$ of PK and $50 \%$ of $\mathrm{PF}+\mathrm{PK})$ throughout the test period. It is especially visible in the early hours of hydration. In general, for all the pastes, the total heat released increases as the time of hydration is longer. However, intensity of heat release is higher in the case of reference paste compared to the samples containing fly ashes. It is especially visible in Figure 2c presenting relative values of the heat evolved calculated in relation to the results for reference paste. The relative values of heat released for cement-fly ash pastes decrease compared to specimen without fly ash up to $8^{\text {th }} \mathrm{h}$ of hydration (delay effect). It shows that hydration processes in the cement-fly ash blends go slowly and it results in elongation of initial setting time. After $8^{\text {th }} \mathrm{h}$ the intensity of heat release begins to gradually increase as a result of further cement hydration as well as development of fly ash activity 
For all the samples the total heat released after $48 \mathrm{~h}$ is significantly lower than for the reference cement paste (the heat for fly ash-cement binders is about $60 \%$ of the value registered for specimen without fly ash). It shows that hydration of cement-fly ash pastes is of lower exothermicity than hydration of Portland cement. Thus, cement-fly ash binders containing $50 \%$ of fly ash have low hydration heat and, for this reason, they can be considered to use for massive constructions. This is also met for samples containing PF. However, fluidized fly ash can show different chemical composition (e.g. fly ash used in Nguyen, Chang, Shih, Chen, and Nguyen (2015) and Škvára et al. (2016)) including high amount of $\mathrm{CaO}$ and sulfate. Highly exothermic hydration of free $\mathrm{CaO}$ can result in increase of temperature of fly ash-cement mix. Thus, in the case of different fluidized fly ashes, their composition and thermal effect of hydration should be evaluated, as it determine the possibility to use this kind of material in high amount in binding mixture. In the case of too high exothermicity of hydration of PF-containing binder, modification of its composition by mixture with conventional fly ash can be considered. Estimation of the amount of hydration heat by continuous calorimetric measurements is a useful technique, especially for comparative studies, to select compositions of preferred level of total heat released. The next step of investigation should be registration of the hydration heat according to PN-EN 196-9:2010 (Polski Komitet Normalizacyjny, 2010) standard requirements and classification of the new binders.

TG/DTG curves (Figure 3) show three main mass losses typical for cement pastes: up to temperature about $420{ }^{\circ} \mathrm{C}$ - dehydration of hydrates type of C-S-H, C-A-S-H, ettringite etc. (abbreviations used in cement chemistry: $\left.\mathrm{C}-\mathrm{CaO}, \mathrm{S}-\mathrm{SiO}_{2}, \mathrm{~A}-\mathrm{Al}_{2} \mathrm{O}_{3}, \mathrm{H}-\mathrm{H}_{2} \mathrm{O}\right)$, from 420 to $480{ }^{\circ} \mathrm{C}-$ decomposition of $\mathrm{Ca}(\mathrm{OH})_{2}$, above $550{ }^{\circ} \mathrm{C}-$ decomposition of carbonates and reduction of $\mathrm{Fe}_{2} \mathrm{O}_{3}$ and $\mathrm{CaSO}_{4}$ with carbon (Payá, Monzó, Borrachero, Perris, \& Amahjour, 1998; van der Merwe, Strydom, \& Potgieter, 1999). In general, similar shapes of the curves, in considered day of hydration, indicate similar qualitative compositions of samples but different quantitative compositions. TG/DTG curves registered at temperature range up to $150{ }^{\circ} \mathrm{C}$ on the $1^{\text {st }}$ day of hydration for paste containing $50 \%$ of $\mathrm{PF}$ and, in lower degree, for paste $50 \%(\mathrm{PK}+\mathrm{PF})$, indicate presence of gypsum (additional effect on DTG which is not observed for $50 \% \mathrm{PK}$ and for the reference). It is a result of introduction of $\mathrm{CaSO}_{4}$ coming from PF. This effect disappears over time confirming that gypsum undergoes chemical reactions. Simultaneously, increase of the mass loss at about $100{ }^{\circ} \mathrm{C}$ corresponding to the presence of C-S-H and ettringite-type phases takes place.

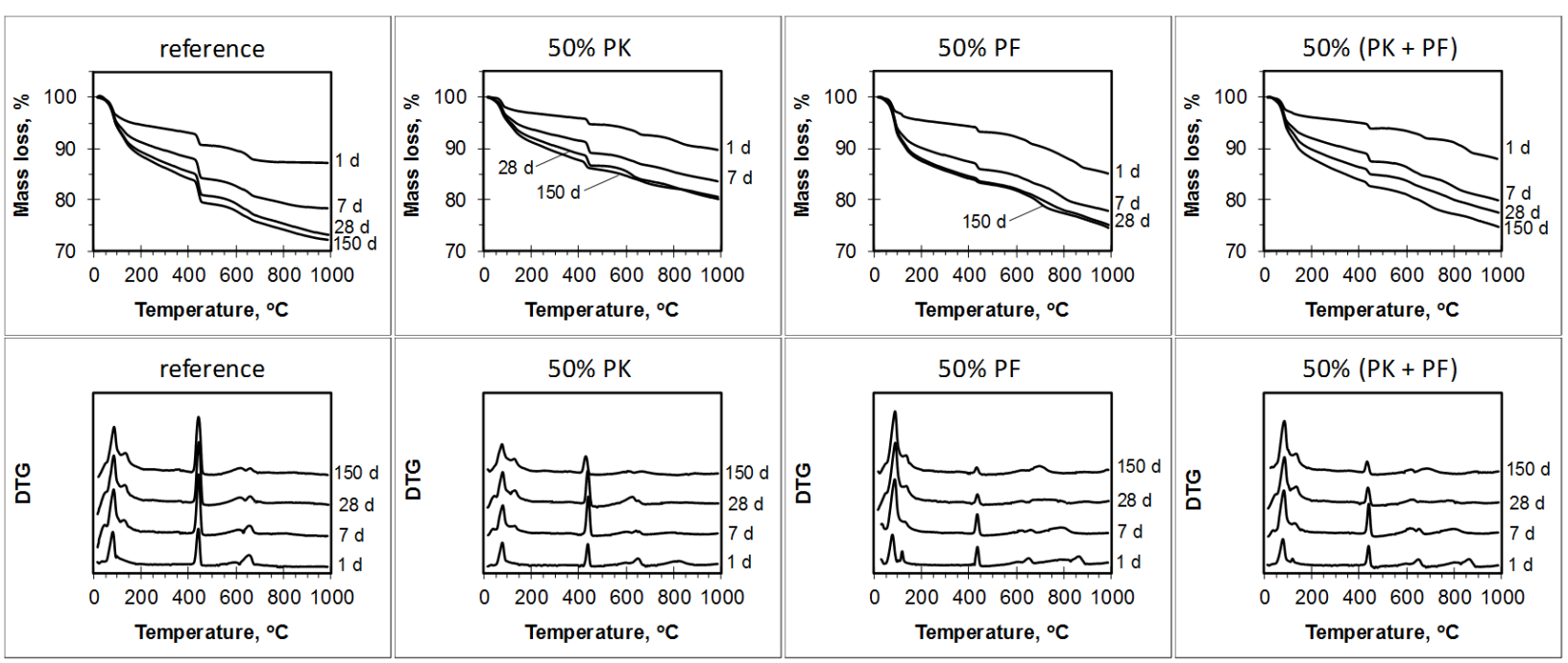

Figure 3. TG and DTG curves for cement-fly ash pastes after different days of hydration
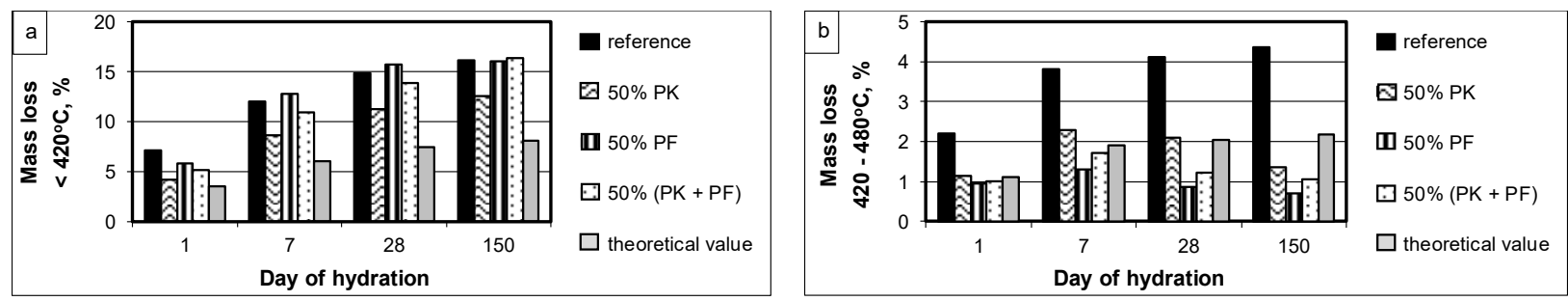

Figure 4. Mass losses at temperature range: up to $420{ }^{\circ} \mathrm{C}$ - evaporation of water bound in hydrates (a) and $420-480^{\circ} \mathrm{C}$ - release of water during decomposition of $\mathrm{Ca}(\mathrm{OH})_{2}(\mathrm{~b})$ 
In general, the mass loss related to dehydration of hydrates increases over time for all pastes while the mass loss corresponding to decomposition of $\mathrm{Ca}(\mathrm{OH})_{2}$ increases only for the reference (Figure 4). Paste containing $50 \%$ of $\mathrm{PK}$ exhibits the lowest amounts of water bound in hydrates (Figure 4a), however higher than theoretical values calculated as percentage reduction of the result for the reference (assuming that the additive is inactive and does not influence hydration of cement). Specimens containing PF quickly bind water and, on $7^{\text {th }}$ day of hydration, $50 \%$ PF paste reaches values exceeding the result of the reference. Probably, formation of ettringite contributes to this. Figure $4 \mathrm{~b}$ presents mass losses related to decomposition of $\mathrm{Ca}(\mathrm{OH})_{2}$ (a value proportional to the amount of $\mathrm{Ca}(\mathrm{OH})_{2}$ in the sample). It is evident that at early hydration days this mass loss for fly ash-containing pastes is close to theoretical value and can even exceed it (for 50\% PK). This is a result of initially low pozzolanic activity of all fly ashes and acceleration of cement hydration by their fine grains (nucleation action). Sample containing 50\% of PF shows the lowest amount of $\mathrm{Ca}(\mathrm{OH})_{2}$ starting from $7^{\text {th }}$ day. It confirms that this kind of fly ash binds $\mathrm{Ca}(\mathrm{OH})_{2}$ faster and C-S-H, C-A-S-H and calcium sulfoaluminates are formed. After 28 days of hydration, 50\% PF-containing paste shows small increase of bound water and also small reduction of $\mathrm{Ca}(\mathrm{OH})_{2}$. It may indicate that $\mathrm{PF}$ in high volume fly ash paste develops its activity mainly during the first month after addition of water. After this period, hydration processes go in moderate way. Probably, ettringite is mainly formed in pores of the structure in the time when the composite is not fully harden and, for this reason, its formation does not worsen later strength. This conclusion needs to be confirmed in further detailed research. However, it was shown previously (Kubissa et al., 2013) that cement-50\% PF concrete can achieve 90-day compressive strength almost 50\% greater in relation to 28-day results. Mixture of PK $+\mathrm{PF}$ develops its activity slower than PF but faster than PK. After 150 days of hydration, thermal analysis results for $50 \%$ $(\mathrm{PK}+\mathrm{PF})$ are similar to those for $50 \% \mathrm{PF}$.

Relationship observed above related to the shapes of TG/DTG curves for pastes containing different fly ashes as well as mass losses were also confirmed in investigation of cement paste separated from cement concrete after $28^{\text {th }}$ day of hardening in water (Figure 5). Linear relationship between the amount of bound water and 28-day compressive strength (according to data presented in (Kubissa et al., 2013) was shown (Figure 5b). The mass loss resulting from presence of $\mathrm{Ca}(\mathrm{OH})_{2}$ in the samples is the lowest for $50 \% \mathrm{PF}$ composition. For $50 \%(\mathrm{PK}+\mathrm{PF})$ it shows an intermediate value between the result registered for $50 \% \mathrm{PF}$ and this one for $50 \% \mathrm{PK}$, similarly as bound water and compressive strength values.
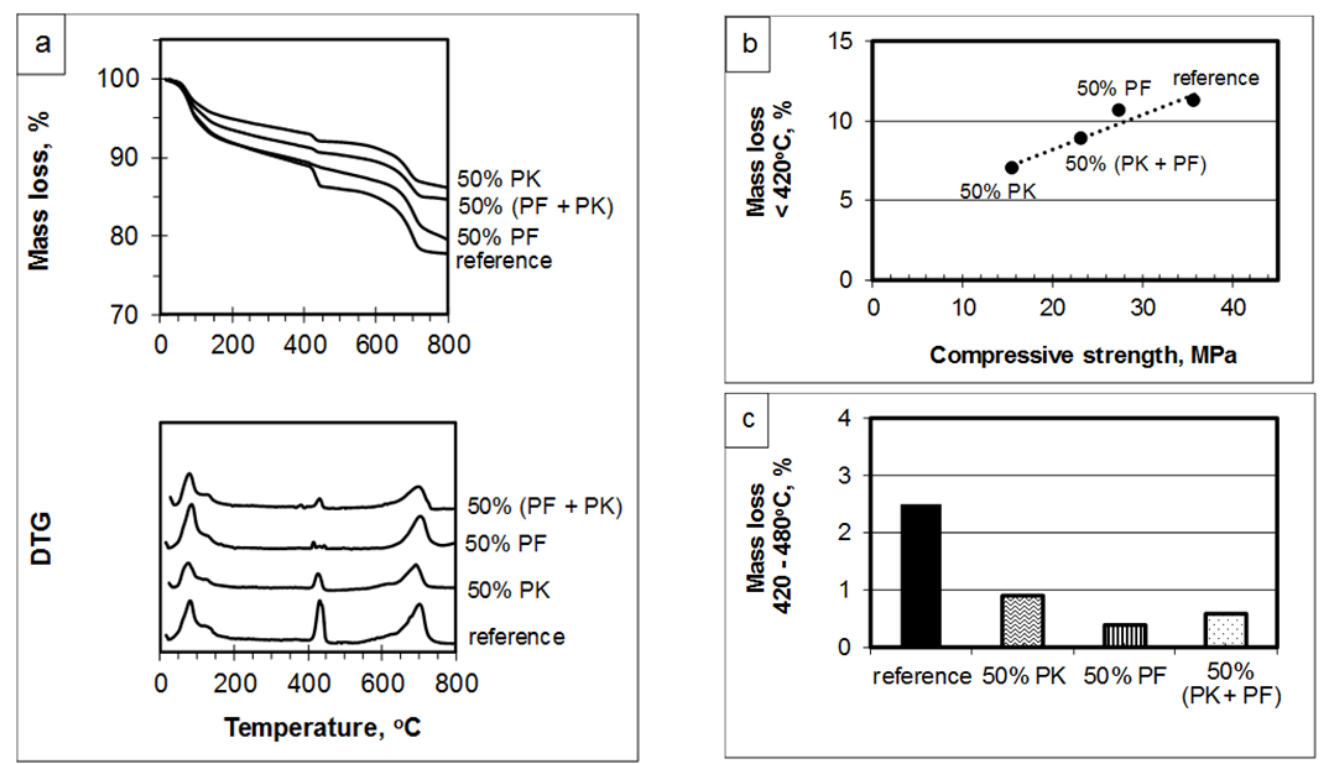

Figure 5. TG and DTG curves for cement paste separated from 28-days old concrete (a), relationship between mass loss up to $420{ }^{\circ} \mathrm{C}$ (evaporation of water bound in hydrates) and compressive strength for the concretes (b) and mass loss at $420-480{ }^{\circ} \mathrm{C}$ (c)

IR spectra (Figure 6) collected for cement-fly ash pastes after 150 days of hydration confirm presence of water (broad band at $3300-3700 \mathrm{~cm}^{-1}$ and middle intensity band at about $1650 \mathrm{~cm}^{-1}$ ), carbonates (the band at $1350-1600 \mathrm{~cm}^{-1}$ ), C-S-H phase (the intense band with the extreme at about $960 \mathrm{~cm}^{-1}$ ). The clear presence of $\mathrm{Ca}(\mathrm{OH})_{2}$ (sharp band at $3640 \mathrm{~cm}^{-1}$ ) is visible only for the reference paste. The higher amount of sulfates in $50 \% \mathrm{PF}$ sample is indicated by the band at about $1090 \mathrm{~cm}^{-1}$. 


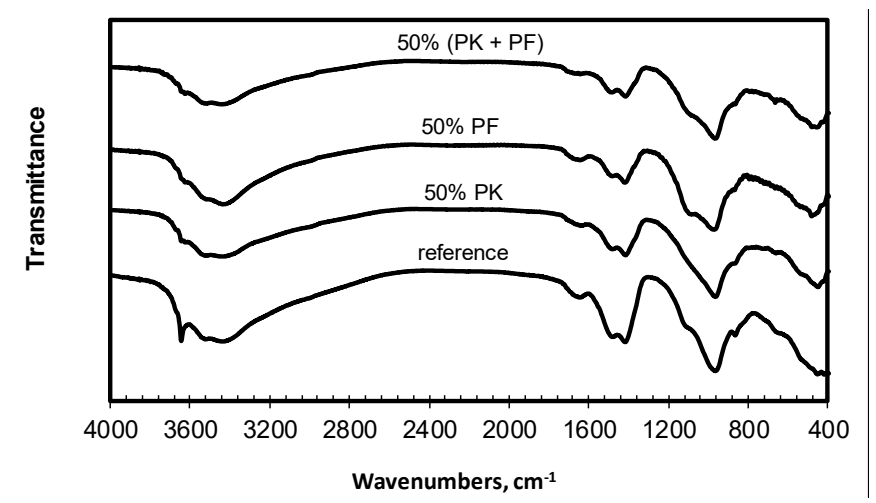

Figure 6. IR spectra for fly ash-cement pastes after 150 days of hydration

\section{Research of cement-fly ash mortar}

Investigation of cement mortar containing $50 \%$ of fly ash shows that such high amount of cement substitute causes very low early compressive strength (on $2^{\text {nd }}$ day of curing, Figure 7). It confirms poor activity of fly ashes at early days and its development between $2^{\text {nd }}$ and $28^{\text {th }}$ day. Comparing with the 2-days results, compressive strength registered on $28^{\text {th }}$ day was higher four, above seven and above five times for samples containing PK, PF and PK + $\mathrm{PF}$, respectively. Further development of compressive strength and its higher values registered on $90^{\text {th }}$ day shows reactivity of cement-fly ash systems. Composition containing 50\% PF shows 90-day compressive strength close to value obtained for $50 \% \mathrm{PK}$, while composition containing PK $+\mathrm{PF}$ has the highest compressive strength both after $28^{\text {th }}$ and $90^{\text {th }}$ day of hardening. For comparison, previous investigation shows 90 -days compressive strength of cement- $50 \% \mathrm{PF}$ concrete above $40 \mathrm{MPa}$ and it was higher than results for $50 \% \mathrm{PK}$ and $50 \%$ of mix PK + PF, close to result for Portland CEM II cement concrete (Kubissa et al., 2013). Because in the case of cement-50\% PF mortar, water to binder ratio was higher than for other compositions, it can be concluded that increase of amount of water improves workability of the mixture but, similarly as in the case of typical cement concrete, it results in higher porosity of hardened composite. It is confirmed by higher water absorptivity and water absorption coefficient (Figure 7b) for specimen containing PF. Thus, mixing of highly porous PF and PK of spherical grains is better solution for composites containing high amount of fly ash. It improves workability of the mixture and provides improvement in compressive strength and sealing the structure.
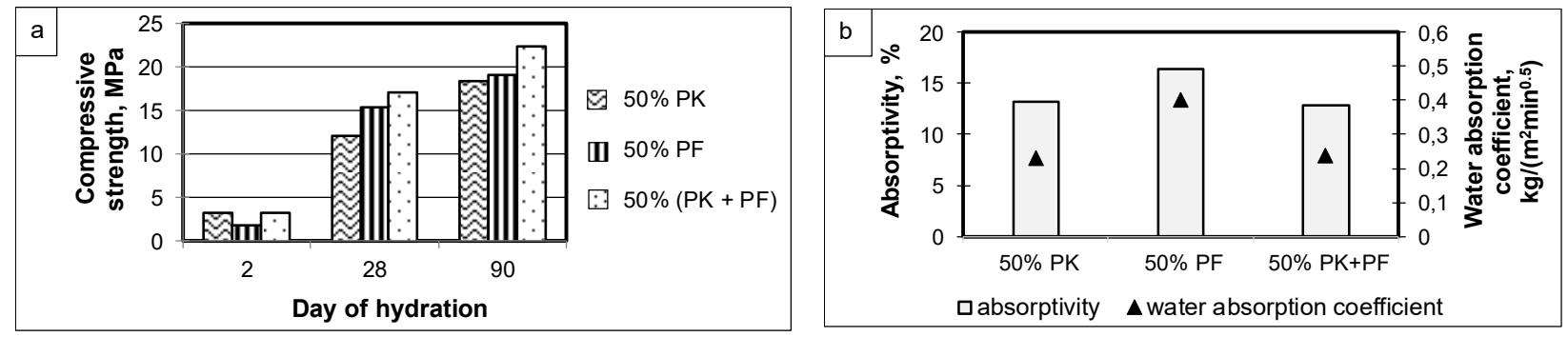

Figure 7. Compressive strength of cement-fly ash mortars after different curing time (a) and water absorption parameters after $60^{\text {th }}$ day (b)

\section{Conclusions}

Fly ash from fluidized combustion of hard coal shows a little self-cementing properties and can be considered as component of high volume fly ash concrete. In this work, using $50 \%$ of this kind of fly ash (or its mixture with conventional fly ash) as cement substitute was proposed. Several conclusions can be drawn basing on results of calorimetric, TG/DTG, IR as well as compressive strength and water absorption investigations.

1. It was confirmed that fluidized fly ash exhibits higher pozzolanic activity than conventional one. This was evident in higher compressive strength of cement mortar containing $25 \%$ of fly ash cement substitution as well as faster and greater reduction of $\mathrm{Ca}(\mathrm{OH})_{2}$ in $50 \%$ fly ash-cement paste. The amount of water bound in hydrates was also higher. The class of Portland cement used influences the rate of development of compressive strength of cement mortar containing fluidized fly ash.

2. Replacement of $50 \%$ of cement by fluidized fly ash results in decrease of total heat released during $48 \mathrm{~h}$ of hydration compared to reference cement paste without cement substitution. This reduction amounts to about 10-20\% during the first 3 hours and about $40 \%$ after 48 hours. After $48 \mathrm{~h}$, the amount of cumulative heat re- 
leased in the case of cement paste with fluidized fly ash is only of about $13 \%$ higher compared to the result of sample containing the same amount of conventional fly ash. Thus, such compositions containing fluidized fly ash can be considered as low-heat release binder to be used in massive concrete structures. Standard requirements for such binders and development of heat release in big mass composite should be confirmed in future research.

3. By means of thermal analysis and IR spectroscopy several components of hardened 50\% fluidized fly ash-cement paste were identified. There are: gypsum (at the early hydration days), sulfoaluminates type of ettringite, C-S-H and C-A-S-H phases, $\mathrm{Ca}(\mathrm{OH})_{2}$, carbonates. Their content changes depending on the time of hydration.

4. Higher reactivity of fluidized fly ash (compared to conventional one) and content of calcium and sulfate compounds cause higher compressive strength of cement mortar and concrete (50\% of cement substitution) compared to composite containing the same amount of conventional fly ash as cement replacement. It is visible after longer hydration period.

5. Fly ash chemical composition as well as workability of $50 \%$ fly ash-cement binder can be modified using mixture of fluidized and conventional fly ash. Such mixture develops its activity more moderately than binder containing $50 \%$ of fluidized fly ash but faster than the one with $50 \%$ of conventional fly ash. In later periods of hydration, mix of these two fly ashes and cement reaches the amount of bound water similar to the reference sample and the amount of $\mathrm{Ca}(\mathrm{OH})_{2}$ is significantly reduced. Composites containing mix of fly ashes can achieve compressive strength even higher than those registered for sample containing fluidized fly ash.

6. This paper shows that fluidized fly ash (used in the research) or its mixture with conventional fly ash can be considered as binder components in cement mortar or concrete. However, fluidized fly ashes coming from different sources can differ significantly in their chemical compositions, including various amounts of $\mathrm{CaSO}_{4}$ and free $\mathrm{CaO}$. In the case of high content of such components, heat released by hydrating mixture can be higher. Moreover creation of delayed expansive phases should be excluded. For this reason, it is necessary to experimentally determine range of changes in physicochemical properties of fluidized ash to make its use in high volume fly ash concrete possible.

\section{Acknowledgements}

The work has been supported by the Town of Płock through the Mayor's Research Grants Programme "Collaboration with Universities".

\section{References}

Batog, M., Golda, A., \& Giergiczny, Z. (2016). Popiół lotny składnikiem betonu masywnego na fundamenty nowych bloków energetycznych. In A. Kornacki (Ed.), Popioły z energetyki. XXIII Międzynarodowa konferencja (pp. 65-76). Zakopane: Polska Unia UPS.

Chen, X., Gao, J., Yan, Y., \& Liu, Y. (2017). Investigation of expansion properties of cement paste with circulating fluidized bed fly ash. Construction and Building Materials, 157, 1154-1162. https://doi.org/10.1016/j.conbuildmat.2017.08.159

Dung, N. T., Chang, T. P., \& Chen, C. T. (2014). Engineering and sulfate resistance properties of slag-CFBC fly ash paste and mortar. Construction and Building Materials, 63, 40-48. https://doi.org/10.1016/j.conbuildmat.2014.04.009

Garcia-Lodeiro, I., Donatello, S., Fernández-Jiménez, A., \& Palomo, Á. (2016). Hydration of hybrid alkaline cement containing a very large proportion of fly ash: A descriptive model. Materials, 9(8), 1-16. https://doi.org/10.3390/ma9070605

Gazdič, D., Fridrichová, M., Kulísek, K., \& Vehovská, L. (2017). The potential use of the FBC ash for the preparation of blended cements. Procedia Engineering, 180, 1298-1305. https://doi.org/10.1016/j.proeng.2017.04.292

Hannesson, G., Kuder, K., Shogren, R., \& Lehman, D. (2012). The influence of high volume of fly ash and slag on the compressive strength of self-consolidating concrete. Construction and Building Materials, 30, 161-168. https://doi.org/10.1016/j.conbuildmat.2011.11.046

Hlaváček, P., Šulc, R., Šmilauer, V., Rößler, C., \& Snop, R. (2018). Ternary binder made of CFBC fly ash, conventional fly ash, and calcium hydroxide: Phase and strength evolution. Cement and Concrete Composites, 90, 100-107. https://doi.org/10.1016/j.cemconcomp.2017.09.020

Horszczaruk, E., \& Brzozowski, P. (2018). Application of fly ash from fluidized bed combustion as addition for underwater concreto. Paper presented at $4^{\text {th }}$ International Conference on Sustainable Development, 11-15 April 2018. Athens, Greece.

Huang, C.-H., Lin, S.-K., Chang, C.-S., \& Chen, H.-J. (2013). Mix proportions and mechanical properties of concrete containing very high-volume of Class F fly ash. Construction and Building Materials, 46, 71-78. https://doi.org/10.1016/j.conbuildmat.2013.04.016

Jackiewicz-Rek, W. (2010). Betony wysokopopiołowe. Materialy Budowlane, 10, 18-20.

Jaskulski, R., Glinicki, M. A., Ranachowski, Z., \& Kubissa, W. (2019). Organic phosphorus compounds as heat release regulators in hardening shielding concrete. Construction and Building Materials, 209, 167-175. https://doi.org/10.1016/j.conbuildmat.2019.03.081 
Jason, L., \& Masson, B. (2014). Comparison between continuous and localized methods to evaluate the flow rate through containment concrete structures. Nuclear Engineering and Design, 277, 146-153. https://doi.org/10.1016/j.nucengdes.2014.06.010

Kledyński, Z., Machowska, A., Pacewska, B., \& Wilińska, I. (2017). Investigation of hydration products of fly ash-slag pastes. Journal of Thermal Analysis and Calorimetry, 130(1), 351-363. https://doi.org/10.1007/s10973-017-6233-4

Knor, G., Glinicki, M., Holnicki-Szulc, J., Ossowski, A., \& Ranachowski, Z. (2014). Influence of calcareous fly ash on the temperature of concrete in massive elements during the first 72 hours of hardening. Roads and Bridges - Drogi I Mosty, $12(1), 113-126$.

Kubissa, W., Wilińska, I., \& Pałuba, M. (2013). Badanie właściwości betonów cementowych wykonanych z udziałem odpadów przemysłowych. Przeglad Budowlany, 84, 35-39.

Kurdowski, W. (2010). Chemia cementu i betonu. Stowarzyszenie Producentów Cementu.

Kuriakose, B., Rao, B. N., \& Dodagoudar, G. R. (2016). Early-age temperature distribution in a massive concrete foundation. Procedia Technology, 25, 107-114. https://doi.org/10.1016/j.protcy.2016.08.087

Lee, M. H., Khil, B. S., \& Yun, H. D. (2014). Influence of cement type on heat of hydration and temperature rise of the mass concrete. Indian Journal of Engineering and Materials Sciences, 21(5), 536-542.

Li, X.-G., Chen, Q.-b., Huang, K.-z., Ma, B.-g., \& Wu, B. (2012). Cementitious properties and hydration mechanism of circulating fluidized bed combustion (CFBC) desulfurization ashes. Construction and Building Materials, 36, 182-187. https://doi.org/10.1016/j.conbuildmat.2012.05.017

Lothenbach, B., Scrivener, K., \& Hooton, R. D. (2011). Supplementary cementitious materials. Cement and Concrete Research, 41(12), 1244-1256. https://doi.org/10.1016/j.cemconres.2010.12.001

Machowska, A., Kledyński, Z., Wilińska, I., \& Pacewska, B. (2019). A study of the early hydration processes and properties of fly ash-slag binders. Bulletin of Materials Science, 42, 213. https://doi.org/10.1007/s12034-019-1886-1

van der Merwe, E. M., Strydom, C. A., \& Potgieter, J. H. (1999). Thermogravimetric analysis of the reaction between carbon and $\mathrm{CaSO}_{4} * 2 \mathrm{H}_{2} \mathrm{O}$, gypsum and phosphogypsum in an inert atmosphere. Thermochimica Acta, 341, 431-437. https://doi.org/10.1016/S0040-6031(99)00287-7

Nguyen, H.-A., Chang, T.-P., Shih, J.-Y., Chen, C.-T., \& Nguyen, T.-D. (2015). Influence of circulating fluidized bed combustion (CFBC) fly ash on properties of modified high volume low calcium fly ash (HVFA) cement paste. Construction and Building Materials, 91, 208-215. https://doi.org/10.1016/j.conbuildmat.2015.05.075

Pacewska, B., Blonkowski, G., \& Wilińska, I. (2006). Investigations of the influence of different fly ashes on cement hydration. Journal of Thermal Analysis and Calorimetry, 86(1), 179-186. https://doi.org/10.1007/s10673-005-7136-7

Pacewska, B., Blonkowski, G., \& Wilińska, I. (2008). Studies on the pozzolanic and hydraulic properties of fly ashes in model systems. Journal of Thermal Analysis and Calorimetry, 94(2), 469-476. https://doi.org/10.1007/s10973-008-9179-8

Pacewska, B., \& Wilińska, I. (2013). Hydration of cement composites containing large amount of waste materials. Procedia Engineering, 57, 53-62. https://doi.org/10.1016/j.proeng.2013.04.009

Pacewska, B., Wilińska, I., \& Bukowska, M. (2009). Calorimetric investigations of the influence of waste aluminosilicate on the hydration of different cements. Journal of Thermal Analysis and Calorimetry, 97(1), 61-66. https://doi.org/10.1007/s10973-008-9668-9

Pacewska, B., Wilińska, I., \& Nowacka, M. (2011). Studies on the influence of different fly ashes and Portland cement on early hydration of calcium aluminate cement. Journal of Thermal Analysis and Calorimetry, 106(3), 859-868. https://doi.org/10.1007/s10973-011-1570-1

Payá, J., Monzó, J., Borrachero, M. V., Perris, E., \& Amahjour, F. (1998). Thermogravimetric methods for determining carbon content in fly ashes. Cement and Concrete Research, 28(5), 675-686. https://doi.org/10.1016/S0008-8846(98)00030-1

Polski Komitet Normalizacyjny. (2012). Fly ash for concrete. Definition, specifications and conformity criteria (PN-EN 450-1). Polish Committee for Standardization, Warsaw.

Polski Komitet Normalizacyjny. (2000). Methods of test for mortar for masonry. Bulk sampling of mortars and preparation of test mortars (PN-EN 1015-2). Polish Committee for Standardization, Warsaw.

Polski Komitet Normalizacyjny. (2016). Methods of testing cement. Determination of strength (PN-EN 196-1:2016-07). Polish Committee for Standardization, Warsaw.

Polski Komitet Normalizacyjny. (2003). Methods of test for mortar for masonry. Determination of water absorption coefficient due to capillary action of hardened mortar (PN-EN 1015-18). Polish Committee for Standardization, Warsaw.

Polski Komitet Normalizacyjny. (2010). Methods of testing cement. Heat of hydration. Semi-adiabatic method (PN-EN 196-9:2010). Polish Committee for Standardization, Warsaw.

Poznański, J. (2012). Computer software for processing of data obtained from calorimeter.

Ramezanianpour, A. A., Bayat, H., Bagheri, M., \& Moeini, M. A. (2016). The effect of fly ash and blast-furnace slag on mechanical, rheological and durability of self-consolidating concrete-a review. In $5^{\text {th }}$ National and $1^{\text {st }}$ International Conference on Modern Materials and Structures in Civil Engineering (pp. 1-14). Tehran.

Shen, Y., Qian, J., \& Zhang, Z. (2013). Investigations of anhydrite in CFBC fly ash as cement retarders. Construction and Building Materials, 40, 672-678. https://doi.org/10.1016/j.conbuildmat.2012.11.056

Sheng, G., Li, Q., \& Zhai, J. (2012). Investigation on the hydration of CFBC fly ash. Fuel, 98, 61-66. https://doi.org/10.1016/j.fuel.2012.02.008

Škvára, F., Šulc, R., Snop, R., Zlámalová Cílová, Z., Peterová, A., Kopecký, L., \& Formáček, P. 2016. Czech fluid Sulfocalcic ash and fly ash. Ceramics - Silikaty, 60(4), 344-352. https://doi.org/10.13168/cs.2016.0051 
Sun, J., Shen, X., Tan, G., \& Tanner, J. E. (2018). Compressive strength and hydration characteristics of high-volume fly ash concrete prepared from fly ash. Journal of Thermal Analysis and Calorimetry, 136(2), 565-580. https://doi.org/10.1007/s10973-018-7578-z

Tahersima, M., Ley, T., \& Tikalsky, P. (2017). Hydration heat in a mass concrete and a thin slab with limestone blended cement. International Journal of Materials Science and Engineering, 5(2), 79-86. https://doi.org/10.17706/ijmse.2017.5.2.79-86

Wilińska, I., \& Pacewska, B. (2019). Comparative investigation of reactivity of different kinds of fly ash in alkaline media. Journal of Thermal Analysis and Calorimetry, 1-16. https://doi.org/10.1007/s10973-019-08296-4

Wilińska, I., \& Pacewska, B. (2018). Influence of selected activating methods on hydration processes of mixtures containing high and very high amount of fly ash: A review. Journal of Thermal Analysis and Calorimetry, 133(1), 823-843. https://doi.org/10.1007/s10973-017-6915-y

Xia, Y., Yan, Y. \& Hu, Z. (2013). Utilization of circulating fluidized bed fly ash in preparing non-autoclaved aerated concrete production. Construction and Building Materials, 47, 1461-1467. https://doi.org/10.1016/j.conbuildmat.2013.06.033

Zhang, W., Choi, H., Sagawa, T., \& Hama, Y. (2017). Compressive strength development and durability of an environmental load-reduction material manufactured using circulating fluidized bed ash and blast-furnace slag. Construction and Building Materials, 146, 102-113. https://doi.org/10.1016/j.conbuildmat.2017.04.042

Zreiki, J., Bouchelaghem, F., \& Chaouche, M. (2010). Early-age behaviour of concrete in massive structures, experimentation and modelling. Nuclear Engineering and Design, 240(10), 2643-2654. https://doi.org/10.1016/j.nucengdes.2010.07.010 